\title{
GRAPE SEED EXTRACT VERSUS CAPTOPRIL IN AMELIORATING 5-FLUOROURACIL-INDUCED NEPHROTOXICITY IN ADULT MALE ALBINO RATS: BIOCHEMICAL, HISTOLOGICAL AND IMMUNOHISTOCHEMICAL STUDY
}

\author{
By
}

\section{Wesam Abd El-Salam Abd El-Wahab ${ }^{a}$, Amal Abd El-Majid Ahmed ${ }^{a}$ and Mona Mohamed Abd El-Galil ${ }^{\text {b* }}$}

Forensic Medicine \& Clinical Toxicology Department, Faculty of Medicine (Girls), AlAzhar University,11651,Cairo, Egypt

b* Histology Department, Faculty of Medicine (Girls), Al-Azhar University,11651,Cairo, Egypt

*Corresponding author: Mona Mohamed Abd El-Galil

Histology Department, Faculty of Medicine (Girls), Al-Azhar University, Cairo, Egypt Phone No.: (+2) 01090305671

E-mail address: medicalmona2009@yahoo.com

\section{Authors e-mail addresses: \\ w_abdalwahab@yahoo.com}

Forensic Medicine \& Clinical Toxicology Department, Faculty of Medicine (Girls), AlAzhar University, Cairo, Egypt

Institutional email address: $\underline{w}$ _abdalwahab@azhar.edu.eg

\section{amal.mohamed53@yahoo.com}

Forensic Medicine \& Clinical Toxicology Department, Faculty of Medicine (Girls), AlAzhar University, Cairo, Egypt

Institutional email address: amalabdelmeged.medg@azhar.edu.eg

\begin{abstract}
Background: 5-Fluorouracil (5-FU) is one of the extensively used chemotherapeutic agents for different human malignancies. It has severe side effects and is considered a nephrotoxic agent. Captopril is one of the angiotensin-converting enzyme inhibitors (ACEI) used in treatment of hypertension and congestive heart failure. It is also an effective radical scavenger and antioxidant due to its free thiol group. Grape seeds extract is one of the effective radical scavengers with antioxidant, anti-proliferative and anti-inflammatory properties.

Objective: The present study was designed to assess the probable protective role of captopril and grape seeds extract against 5-FU-induced nephrotoxicity in adult male albino rats.
\end{abstract}


Materials and Methods: Forty eight adult male albino rats were divided into 8 equal groups;

Group I kept as the control group, Group II (grape seeds consumed group), received aqueous grape seeds extract $(500 \mathrm{mg} / \mathrm{kg} /$ day) orally by gastric tube. Group III (captopril group), injected intraperitoneally by captopril solution $(60 \mathrm{mg} / \mathrm{kg}$ ) once daily. Group IV (grape seeds \& captopril), Group V (5-Fluorouracil group), injected intraperitoneally by 5 -FU solution $(20 \mathrm{mg} / \mathrm{kg}$ ) once daily. Group VI (grape seeds/5-FU), Group VII (captopril/5-FU) and Group VIII (grape seeds \& captopril/5-FU). Treatment was continued at the same time daily for 4 weeks. At the end of the experiment, final body weight, blood urea nitrogen (BUN), creatinine $(\mathrm{Cr})$ and uric acid levels were measured. Also, specimens of right kidneys were taken for histological and immunohistochemical studies with anti-inducible nitric oxide synthase (iNOS).

Results: 5-FU resulted in a significant reduction in final body weight and a significant elevation of (BUN), (Cr) and uric acid levels. Moreover, glomerular and tubular distortion, vacuolated epithelial lining, intraluminal acidophilic hyaline casts, congested peritubular capillaries, interstitial inflammatory infiltration, and increased fibrosis within the renal interstitium. The immunohistochemical expression of iNOS supported kidney impairment in the 5-FU group. Treatment with either grape seeds or captopril revealed some improvement in the final body weight, biochemical markers and histological changes. The best effect was encountered when grape seeds and captopril were combined.

Conclusion: and Recommendation: Grape seeds and captopril succeeded in ameliorating 5-FU induced nephrotoxicity with a better effect by their combination. So, it is recommended to use grape seeds extract and captopril during chemotherapy with 5 fluorouracil to reduce its renal toxicity.

Keywords: Chemotherapy; 5-Fluorouracil; grape seeds; captopril; nephrotoxicity.

\section{INTRODUCTION}

Cancer is the subsequent driving reason for death in the world. Chemotherapy is the commonest treatment. However, chemotherapy, induced severs unfavorable impacts. Hence, it is critical to develop effective management strategies against chemotherapy and radiotherapy-induced adverse effects (Zhang et al., 2018).

A widely antineoplastic drug used is the fluorinated uracil molecule 5Fluorouracil (5-FU). This molecule is an antineoplastic antimetabolic of the pyrimidine base uridine. It acts as a false substrate in the synthesis process of the essential constituents of nucleic acids, causing synthesis of an anomalous DNA (Casanova et al., 2017).

5-Fluorouracil (5-FU) has been commonly prescribed for patients with a large variety of tumors (Marjaneh et al., 2019). It is used orally or intravenously, absorbed in the intestine, rapidly distributed throughout the body and metabolized in the liver giving rise to its active metabolite that is being eliminated by several mechanisms (Woloch et al., 2012). Although 5-FU generates acceptable outcome, it exhibits severe toxicity and undesirable side effects (Narimatsu et al., 2019).

Captopril is one of the angiotensinconverting enzyme inhibitors (ACEI) used in treatment of hypertension and congestive heart failure. It is also an effective radical scavenger and antioxidant due to its free thiol group (Kancirová et al., 2016).

In addition to its ability to reduce blood pressure, captopril has several other biological activities. Zhou et al. (2015) have suggested that captopril protects the kidney against progressive long-term renal damage.

Retrospective studies on cancer patients showed that cardioprotective interventions with ACEI lead to a 
recovery of myocardial function and reduction of cardiac events, thus allowing patients to complete cancer therapy (Morbidelli et al., 2016).

Grapes are one of the most consumed fruits in the world and are very rich in antioxidants. Polyphenols are the most precious phytonutrients of grape that have several health-promoting effects as chemo preventive and chemotherapeutic effects in various cancer animal models and cell cultures (Singh et al., 2016).

DE Moura et al. (2019) demonstrated the chemopreventive activity of grape seeds extract in oral carcinogenesis assays in male Wistar rats as depicted by its antioxidant, anti-proliferative and antiinflammatory properties.

So, this study was designed to assess the probable protective role of grape seeds extract and captopril against 5-FUinduced nephrotoxicity in adult male albino rats.

\section{MATERIALS AND METHODS}

\section{Animals:}

Forty eight adult male Wistar albino rats aging 8 weeks and weighing 150-180 $\mathrm{g}$ were chosen for the study. Rats were purchased from Helwan Breeding farm, Egypt. Animals were settled under normal laboratory conditions with room temperature of $23 \pm 2^{\circ} \mathrm{C}$, humidity of $(54 \pm$ $5 \%$ ) and alternating light/dark cycles in conventional clean properly ventilated wire-mesh cages $(25 \times 30 \times 25 \mathrm{~cm}-3$ rats per cage) at the animal house, Faculty of Medicine (Girls), Al-Azhar University, Cairo, Egypt. Rats were acclimated, one week for adaptation before beginning the experiment. They were fed on normal chow diet and allowed free access to water throughout the experiment. All the ethical protocols for animal treatment were followed in accordance with the Research Ethics Committee (FMG-IRB), Faculty of Medicine (Girls), Al-Azhar University.

\section{Drugs and chemicals:}

Fluorouracil (Biosynth Company): It was provided in $5 \mathrm{ml}$ ampoules packaging, each containing $250 \mathrm{mg}$ 5Fluorouracil. Each ampoule was dissolved in $80 \mathrm{ml}$ of normal saline, and $1 \mathrm{ml} \mathrm{(3}$ $\mathrm{mg} / \mathrm{ml}$ ) was given intraperitoneally (i.p) at a therapeutic dose of $20 \mathrm{mg} / \mathrm{kg} /$ day, for 4 weeks (Rashid et al., 2014).

Captopril: A commercially available formulation (Captopril $50 \mathrm{mg}$ scored tablet, Egyptian International Pharmaceutical Company "EPICO", Egypt) was used. $50 \mathrm{mg}$ was dissolved in $5 \mathrm{ml}$ of normal saline, then $1 \mathrm{ml}$ of the prepared solution $(10 \quad \mathrm{mg} / \mathrm{ml})$ administered intraperitoneally (i.p.) in a daily dose equivalent to $60 \mathrm{mg} / \mathrm{kg} /$ day, for 4 weeks (Gad et al., 2016).

Grape seeds extract (GSE): A commercially available formulation (Gervital capsules, each contained $150 \mathrm{mg}$ GSPE (Vitis Vinifera) with $96 \%$ purity of proanthocyanidin, Arab Company for Pharmaceuticals and Medicinal Plants (MEPACO), Cairo, Egypt. Each capsule was dissolved in $2 \mathrm{ml}$ distilled water, then $1 \mathrm{ml}$ of the aqueous solution $(75 \mathrm{mg} / \mathrm{ml})$ was given by gastric intubation in a daily dose equivalent to $500 \mathrm{mg} / \mathrm{kg}$, for four weeks (Jhun et al., 2013). 


\section{Experimental design}

\section{Rats were divided into 8 equal groups:}

- Group I (control group): Six adult male albino rats received equivalent volume $(1 \mathrm{ml})$ of normal saline by intraperitoneal injection once daily, for 4 weeks.

- Group II (grape seeds extract group): Six adult male albino rats received $1 \mathrm{ml}$ of grape seeds extract solution orally at a dose of $(500 \mathrm{mg} / \mathrm{kg} /$ day $)$ by a gastric gavage, in the early morning for four weeks.

- Group III (captopril treated group): Six adult male albino rats received $1 \mathrm{ml}$ of the prepared captopril solution (60 $\mathrm{mg} / \mathrm{kg}$ ) once daily by intraperitoneal injection, for 4 weeks.

- Group IV (grape seeds extract and captopril treated group): Six adult male albino rats received grape seeds extract solution orally + intraperitoneal injection of captopril by the same doses and duration.

- Group V (5-Fluorouracil group): Six adult male albino rats were injected i.p. by $1 \mathrm{ml}$ of 5 -FU solution $(20 \mathrm{mg} / \mathrm{kg})$ once daily, for 4 weeks.

- Group VI (grape seeds/5-FU group): Six adult male albino rats received grape seeds extract solution orally 1 hour prior to intraperitoneal injection of 5-FU solution by the same doses and duration.

- Group VII (captopril/5-FU group): Six adult male albino rats received the prepared captopril solution i.p. 1 hour prior to intraperitoneal injection of 5FU solution by the same doses and duration.
- Group VIII (grape seeds extract \& captopril / 5-FU group): Six adult male albino rats received grape seeds extract solution orally + intraperitoneal injection of captopril 1 hour prior to i.p. injection of 5-FU by the same doses and duration.

All rats were weighed individually at the beginning of the experimental protocol, and at the end, just before collecting samples.

At the end of the experiment (4 weeks), animals were overnight fasted, blood samples were withdrawn from retro-orbital sinuses by capillary tubes under ether anesthesia, centrifuged at 3000 round per minute to separate the serum that was maintained in a freezer at $80^{\circ} \mathrm{C}$ until analysis for detection of blood urea nitrogen $(\mathrm{BUN})$, creatinine $(\mathrm{Cr})$ and uric acid levels. These parameters were estimated by the conventional colorimetric method using Quanti Chrom TM assay kits (Abdel Aziz et al., 2011) according to the manufacturer's instruction (Bio Assay Systems, CA 94545, USA). These biochemical studies were done in El Nour Global Lab, Cairo, Egypt. A midline incision was done on the anterior aspect of the abdomen, and the right kidney samples were excised and processed for light microscopic and immunohistochemical examination.

Preparation of specimens for light microscopic and immunohistochemical studies:

Samples from the right kidney were immediately fixed in $10 \%$ buffered formalin for 72 hours, dehydrated in ascending grades of ethyl alcohol, followed by clearance in xylene, impregnation and embedding in paraffin 
wax to obtain paraffin blocks. Sections of $5 \mu \mathrm{m}$ thickness were cut, mounted on slides and stained with the following: (Bancroft and Layton, 2013).

1. Hematoxylin and Eosin (H\&E) stain for studying the general histological structure.

2. Masson's Trichrome stain for staining the collagen fibers.

3. Periodic Acid-Schiff (PAS) reaction to demonstrate the presence of mucopolysaccharides and detection of tubular apical brush borders, glomerular and tubular basement membrane of the renal tissue.

4. The immunohistochemical technique was used to evaluate nuclear inducible nitric oxide synthase (iNOS) expression in deparaffinized formalinfixed renal sections using an avidinbiotin-peroxidase complex immunohistochemical method against iNOS (1:200 dilution; Thermo Fisher Scientific, catalogue \# PA1-036, RRID AB_325773). Briefly, $5 \mu \mathrm{m}$ deparaffinized renal sections were obtained on positive charged slides, heat-induced antigen retrieval was performed using citrate buffer $\mathrm{pH} 6(10$ Mm, 20 min) (cat number AP 9003) for antigen retrieval, followed by blocking endogenous peroxidase activity using $0.3 \% \mathrm{H} 2 \mathrm{O} 2$ in methanol for 20 minutes, and tissues were then probed at a dilution of 1:200 with a rabbit polyclonal primary antibody recognizing iNOS overnight at $4^{\circ} \mathrm{C}$ in a humidified chamber according to the manufacturer's instructions. Tissues were washed extensively with phosphate-buffered saline (PBS) and endogenous peroxidase activity was quenched with a peroxidase suppressor. Using a universal detection kit (Dakocytomation), few drops of biotinylated secondary antibodies were applied for $15 \mathrm{~min}$, formed a complex with peroxidase-conjugated streptavidin molecules. Sections were rinsed and followed by colorimetric detection using the prepared diaminobenzidine tetra-hydro chloride (DAB) substrate chromogen solution for $15 \mathrm{~min}$ until the desired brown color obtained. Finally, sections were counterstained with Mayer's hematoxylin and prepped for mounting (Yurdakan et al., 2012). Negative controls were processed by incubating the sections with PBS instead of primary antibody (Fig.1a). Positive staining was defined microscopically by visual identification of brown stained immunoreactive cells (Fig.1b). Immunohistochemistry was performed at The Cancer Institute, Cairo University. 


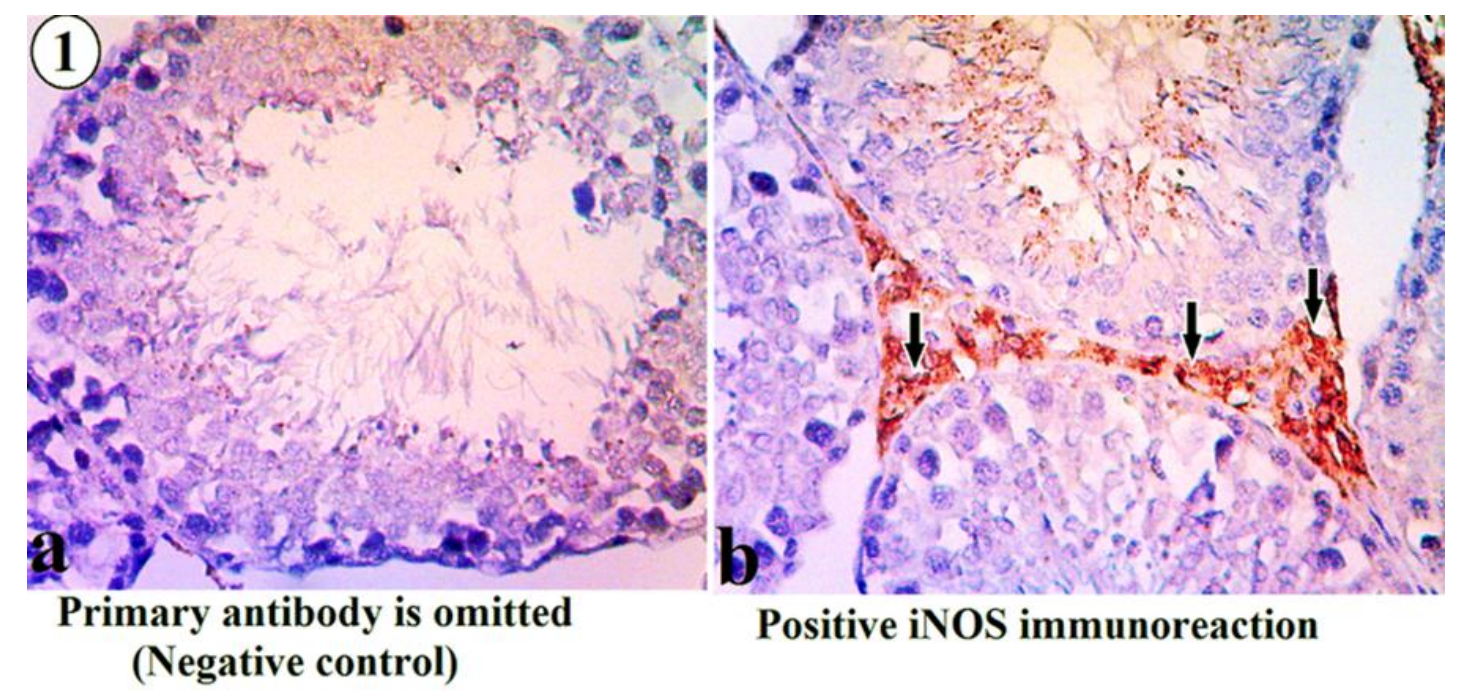

Figure (1): A photomicrograph of iNOS staining in the testicular tissue sections: (a) primary antibody is omitted (negative control). (b) Positive immunohisto staining for iNOS (arrows) after secondary antibody. (iNOS immunoreaction, $x$ 400).

\section{Histo-morphometric measurements:}

All sections were examined, photographed by Leica DM2500 optical microscopes (Leica microsystems, Nussloch, Germany) coupled to a Leica digital camera, and transferred to the screen using a computerized image analyzer Leica Q500 MC program (Leica Microsystems Ltd, Cambridge, UK). The data were calibrated automatically to convert the measurement units (pixels) produced by image analyzer program into actual micrometer units. Ten different non overlapping randomly selected fields from five different renal sections in each group from all experimental groups were examined to quantitatively evaluate the following:

- The glomerular and tubular diameters of round or nearly round renal glomeruli, proximal convoluted tubules (PCT) and distal convoluted tubules (DCT) in H\&E stained sections at $\mathrm{X}$ 200 magnification (Kotyk et al., 2016).
- The mean area percentage of the green stained collagen fibers in Masson's trichrome stained sections at X 400 magnification (Abdel-Aal et al., 2016).

- The mean optical density of PAS reaction in PAS stained sections at $\mathrm{X}$ 400 magnification (Salib et al., 2019).

- Finally, the mean area percentage of the iNOS immunopositive expressed cells were estimated at X 400 magnification (Bayomy et al., 2017).

All histomorphometric measurements were carried out at the Regional Center for Mycology and Biotechnology (RCMB), Al-Azhar University, Cairo, Egypt.

\section{Statistical Analysis:}

All data were statistically expressed as means $\pm \mathrm{SD}$, and compared using the oneway analysis of variance (ANOVA) followed by Tukey's post hoc test. Level of probability (P-value) less than 0.05 was used as the criterion of significance. 
Statistical analysis was performed using the Statistical Package for the Social
Sciences, Version 20 for Windows (SPSS

Inc., Chicago, Illinois, USA).

\section{RESULTS}

The statistical comparison between the control, grape seeds, captopril and combined grape seeds with captopril revealed no significant difference ( $>0.05$ ). Therefore, all comparisons were referred to the control group.

\section{Effect on body weight:}

The mean values of initial body weight (IBW) of all studied groups at the beginning of the experiment were nearly similar with no statistically significant difference between them.
At the end of the experiment, the least recorded mean of final body weight was among 5FU-treated rats as compared to the control rats. Combined GSE \& Cap with $5 \mathrm{FU}$ recorded the highest mean value followed by GSE/5-FU and Cap/5-FU groups respectively on comparable to the 5FU-treated group. All these values were of statistically significant difference $[\mathrm{P}<$ 0.001] (Table 1).

Table (1): One-way ANOVA comparative statistical analysis of the mean initial and final body weight in rats of different groups

\begin{tabular}{|c|c|c|c|c|c|c|c|c|c|}
\hline $\begin{array}{l}\text { Groups } \\
\text { Parameters }\end{array}$ & $\begin{array}{l}\text { Control } \\
(\mathbf{n}=6)\end{array}$ & $\begin{array}{l}\text { GSE } \\
(n=6)\end{array}$ & $\begin{array}{l}\text { C a p } \\
(n=6)\end{array}$ & $\begin{array}{c}\text { GSE\& } \\
\text { Cap } \\
(n=6)\end{array}$ & $\begin{array}{l}5 \text { F U } \\
(n=6)\end{array}$ & $\begin{array}{l}\text { G S E } \\
/ 5 F U \\
(n=6)\end{array}$ & $\begin{array}{l}\text { C a p } \\
/ 5 \text { F U } \\
(n=6)\end{array}$ & $\begin{array}{l}\text { GSE\&Cap } \\
\text { / } 5 \text { F U } \\
(\mathbf{n}=\mathbf{6})\end{array}$ & $P$ \\
\hline $\begin{array}{l}\text { I B W } \\
(\mathrm{g} \pm \text { SD })\end{array}$ & $\begin{array}{r}159 \\
\pm 9.2 \\
\end{array}$ & $\begin{array}{r}154 \\
\pm 4.9\end{array}$ & $\begin{array}{l}160 \\
\pm 7.1 \\
\end{array}$ & $\begin{array}{r}164 \\
\pm 6.7 \\
\end{array}$ & $\begin{array}{r}168 \\
\pm 9.9 \\
\end{array}$ & $\begin{array}{r}166 \\
\pm 8.6 \\
\end{array}$ & $\begin{array}{rrr}1 & 64 \\
\pm 11 \\
\end{array}$ & $\begin{array}{lll}170 \\
\pm 10.1 \\
\end{array}$ & $>0.05$ \\
\hline $\begin{array}{l}\text { F B W } \\
(\mathrm{g} \pm \text { SD })\end{array}$ & $\begin{array}{l}230 \\
\pm 8.9\end{array}$ & $\begin{array}{r}220 \\
\pm 6.3\end{array}$ & $\begin{array}{l}218 \\
\pm 4.1\end{array}$ & $\begin{array}{l}226 \\
\pm 12\end{array}$ & $\begin{array}{r}1355 \\
\pm 5.5 \\
\text { a } \quad *\end{array}$ & $\begin{array}{r}208 \\
\pm 12.9 \\
a * b * \\
\end{array}$ & 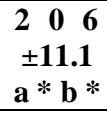 & $\begin{array}{lcc}2 & 2 & 0 \\
& \pm 7.5 \\
\text { b } & *\end{array}$ & $<0.001$ \\
\hline
\end{tabular}

n: number of rats; GSE: grape seeds extract; Cap: captopril; 5FU: 5Fluorouracil; SD: standard deviation; a: in comparison to all groups referred as the control; b: in comparison to the 5FU-treated group.

Effect on serum BUN, Creatinine and uric acid:

Table (2) revealed that the highest recorded mean values of $\mathrm{BUN}$, creatinine and uric acid were among $5 \mathrm{FU}$ treated rats $[\mathrm{P}<0.001]$ as compared to the control rats. Inversely, these parameters significantly improved in combined GSE \& Cap with 5FU group that recorded the least mean values followed by GSE/5-FU and Cap/5-FU pretreated groups respectively comparable to the 5FUtreated group. All these values were of statistically significant difference $[\mathrm{P}<$ 0.001]. However, improvement in the all measured parameters could not reach to the control values as there was a significant difference when compared to the corresponding groups (GSE,Cap and GSE\& Cap). 
Table (2): One-way ANOVA comparativestatistical analysis of the mean blood urea nitrogen, creatinine, and uric acid in rats of different groups

\begin{tabular}{|c|c|c|c|c|c|c|c|c|c|}
\hline Groups & $\begin{array}{c}\text { Control } \\
(n=6)\end{array}$ & $\begin{array}{c}\text { GSE } \\
(n=6)\end{array}$ & $\begin{array}{c}\text { Cap } \\
(n=6)\end{array}$ & $\begin{array}{c}\text { GSE\&Cap } \\
(n=6)\end{array}$ & $\begin{array}{l}5 F U \\
(n=6)\end{array}$ & $\begin{array}{c}\text { GSE/ } \\
5 F U \\
(n=6)\end{array}$ & $\begin{array}{l}\text { Cap/ } \\
5 F U \\
(n=6)\end{array}$ & $\begin{array}{c}\text { GSE\& Cap } \\
\text { /5FU } \\
(n=6)\end{array}$ & $P$ \\
\hline $\begin{array}{c}\text { BUN } \\
(\mathrm{mg} / \mathrm{dl})\end{array}$ & $\begin{array}{l}10.1 \\
\pm 0.4\end{array}$ & $\begin{array}{c}10 \\
\pm 0.2\end{array}$ & $\begin{array}{l}12.5 \\
\pm 0.8\end{array}$ & $\begin{array}{c}10 \\
\pm 0.4\end{array}$ & $\begin{array}{c}26.1 \\
\pm 1.9 \\
a^{*}\end{array}$ & $\begin{array}{c}13.9 \\
\pm 0.4 \\
a * b *\end{array}$ & $\begin{array}{l}14.9 \\
\pm 0.7 \\
a * b *\end{array}$ & $\begin{array}{c}12.2 \\
\pm 0.6 \\
a * b *\end{array}$ & $<0.001$ \\
\hline $\begin{array}{c}\mathrm{Cr} . \\
\text { (mg /dl) }\end{array}$ & $\begin{array}{c}0.6 \\
\pm 0.02\end{array}$ & $\begin{array}{c}0.6 \\
\pm 0.03\end{array}$ & $\begin{array}{c}0.7 \\
\pm 0.04\end{array}$ & $\begin{array}{c}0.5 \\
\pm 0.1\end{array}$ & $\begin{array}{c}3.1 \\
\pm 0.5 \\
a^{*}\end{array}$ & $\begin{array}{c}0.9 \\
\pm 0.1 \mathbf{a}^{*} \mathbf{b}^{*}\end{array}$ & $\begin{array}{c}1.2 \\
\pm 0.4 \\
a * b *\end{array}$ & $\begin{array}{c}0.8 \\
\pm 0.1 \\
a * b *\end{array}$ & $<0.001$ \\
\hline $\begin{array}{l}\text { Uric acid } \\
(\mathrm{mg} / \mathrm{dl})\end{array}$ & $\begin{array}{c}0.6 \\
\pm 0.1\end{array}$ & $\begin{array}{c}0.7 \\
\pm 0.1\end{array}$ & $\begin{array}{c}0.7 \\
\pm 0.1\end{array}$ & $\begin{array}{c}0.7 \\
\pm 0.04\end{array}$ & $\begin{array}{c}5.8 \\
\pm 0.9 \\
a^{*}\end{array}$ & $\begin{array}{c}0.9 \\
\pm 0.3 \\
a * b *\end{array}$ & $\begin{array}{c}1.1 \\
\pm 0.4 \\
a * b *\end{array}$ & $\begin{array}{c}0.9 \\
\pm 0.1 \\
a * b *\end{array}$ & $<0.001$ \\
\hline
\end{tabular}

n: number of rats; GSE: grape seeds extract; Cap: captopril; 5FU: 5Fluorouracil; BUN : blood urea nitrogen, $\mathrm{Cr}$ : creatinine, SD: standard deviation; a: in comparison to all groups referred as the control; b: in comparison to the 5FU-treated group.

\section{Histological and immunohistochemical results:}

Hematoxylin \&Eosin staining:

Histological examination of the renal sections of the control groups revealed normal histoarchitecture of the renal parenchyma in the form of normal renal Malpighian corpuscles, contained tuft of a glomerular capillaries surrounded by Bowman's capsule. The proximal convoluted tubules (PCTs) had narrow lumen lined by a single layer of pyramidal cells with acidophilic cytoplasm, central rounded vesicular nuclei with prominent nucleoli. The distal convoluted tubules (DCTs) had a relatively wider lumen and were lined by cuboidal epithelial cells with less acidophilic cytoplasm and rounded nuclei (Fig.2a). Moreover, the renal medulla revealed wider thin wall collecting tubules lined by low cubical cells and separated by minimum interstitial tissue (Fig.2b).

Interestingly, the GSE (Figs.2.c-d), Cap (Figs.2.e-f) and the combined GSE \& Cap (Figs.2.g-h) groups exhibited a high similarity to the normal renal tissue comparable to the control. Peritubular congestion of renal blood vessels in between collecting tubules in the Cap group was also observed (Fig.2f).
Inversely, $H \& E$ stained sections of the 5-FU treated rats, revealed severe renal histopathological alterations with areas of glomerular and tubular degeneration in the form of expanded renal corpuscles surrounded the congested glomerular capillaries with narrowing of Bowman's spaces. Moreover, congestion of the interstitial blood capillaries as well as extensive interstitial mononuclear inflammatory cell infiltration was frequently detected. Some PCTs and DCTs appeared dilated with epithelial lining exhibited vacuolated cytoplasm and darkly stained nuclei. Some tubules showed exfoliated epithelial cells with acidophilic casts and cellular debris in their lumina (Figs.3a-b).

GSE/5-FU (Figs.3c-d) and Cap/5-FU (Figs.3e-f) groups manifested clear signs of renal tissue recovery where the renal Malphigian corpuscles, PCTs, DCTs and collecting almost restored the usual organization of their lining epithelium, in spite of some vacuolated cells and little cell debris had dark stained nuclei in the lumina of few tubules among apparently normal ones. Moreover, the Cap/5-FU displayed congested peritubular blood capillaries at some areas in the renal medulla (Fig.3f). 
Strangely, dramatical improvement of the renal histoarchitecture was detected in the co-administration of both grape seeds extract and captopril with 5-FU induced rats in spite of apparent widening of urinary spaces and few deeply stained nuclei in the same sections (Figs.3g-h).

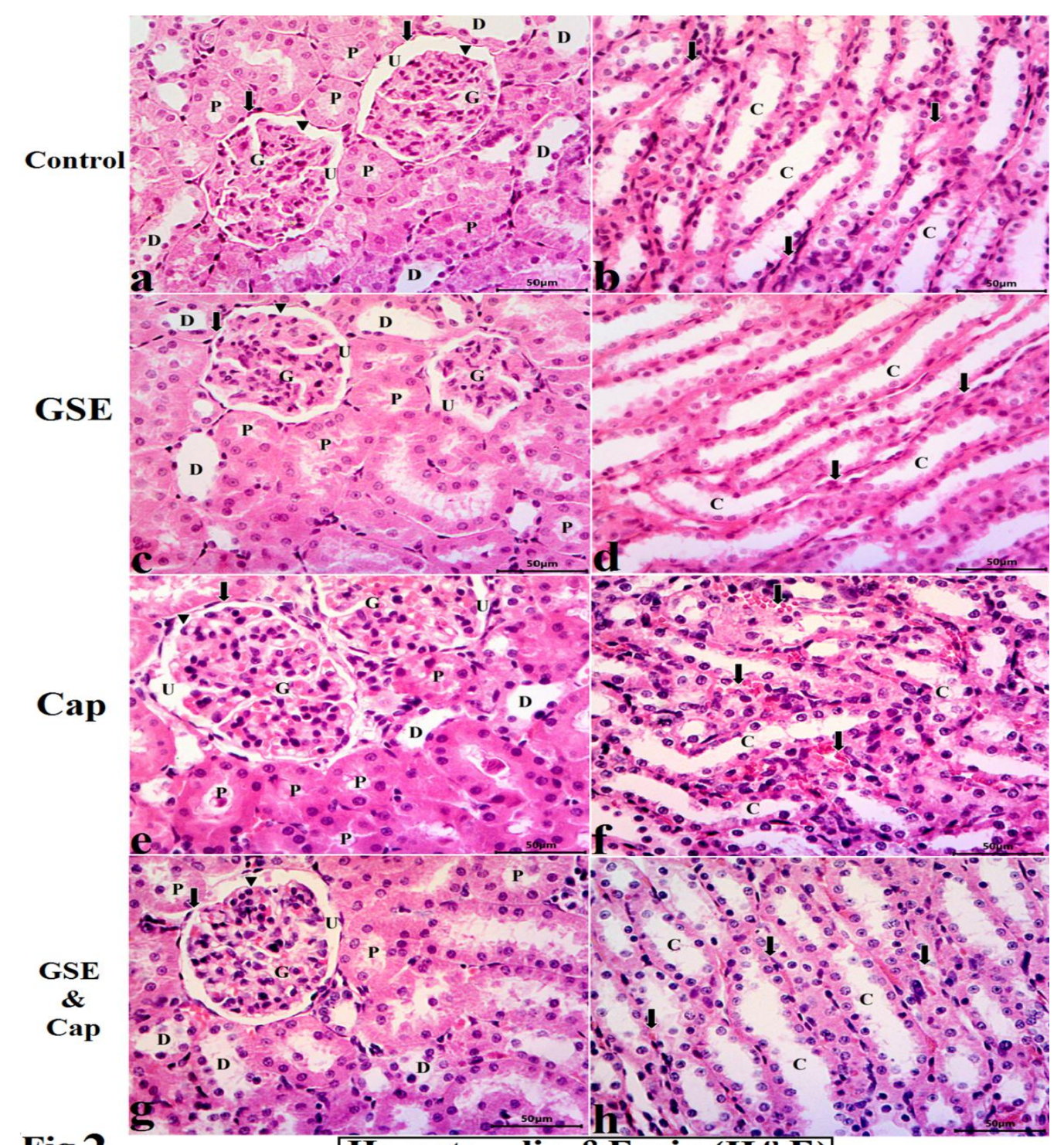

Fig.2

Hematoxylin \&Eosin (H\&E)

Figure (2): (a-b) Control, (a) Normal renal corpuscles consists of glomerulus (G), contains a tuft of capillaries bounded by parietal simple squamous epithelial (black arrow) and visceral layers (arrowhead) of Bowman's capsule, regular urinary space in between (U). Narrow proximal convoluted tubules (P) and wider distal convoluted tubules (D). (b) Low cubical cells of collecting tubules (C) with minimum interstitium (black arrow) in the renal medulla. GSE (c-d), Cap (e-f) and the combined GSE\& CaP (g-h) groups showing normal pattern of renal tissue as the control. Notice, peritubular congestion of blood capillaries in between collecting tubules in the Cap group (H\&E X400, Scale bar; 50 $\mu \mathrm{m})$. 


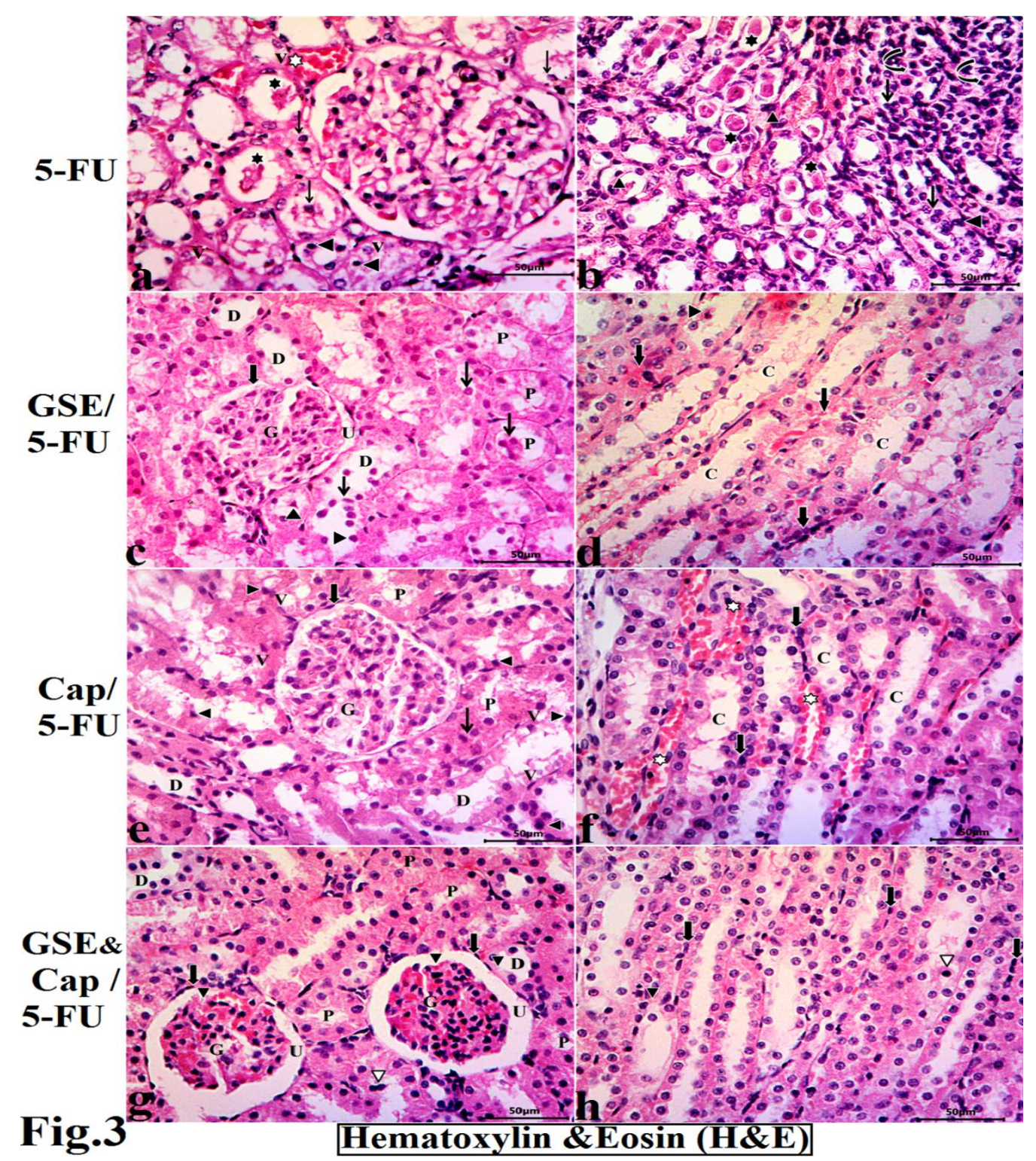

Figure (3): 5-FU treated rats (a-b), demonstrating: Congestion of intraglomerular (G), intertubular blood capillaries (white star). Proximal (P) and distal (D) convoluted tubular epithelial cells have vacuolated cytoplasm (V) with darkly stained nuclei (arrowhead), cell exfoliation into the lumen (black arrow). Interstitial Inflammatory cell infiltrations (curved arrow) and homogenous intratubular acidophilic casts (black star) in some tubules. GSE/5FU (c-d) and Cap/5FU (e-f) groups showing: a potentially alleviated renal architecture in spite of vacuolated (v) and darkly stained exfoliated cells (thin arrow) in some regions. Notice, peritubular blood capillaries congestion (white stars) in between collecting tubules in Cap/5FU (f). Co-treatment with GSE\&Cap/5-FU (g-h) showing: mostly normal renal corpuscles, glomeruli (G) with an apparent widening of the urinary space (U). Proximal (P), distal (D) and collecting. tubules (C) appear with normal structures. Few darkly stained nuclei (arrowheads) are also observed (H\&E X400, Scale bar; 50 $\mu \mathrm{m})$. 
Masson's trichrome stain:

In masson's trichrome stained renal sections of the control group (GI), scanty fine scattered collagen fibers were concentrated mainly around the Bowman's capsule, among the glomerular capillaries and in the interstitium between renal tubules (Figs.4a-b). Masson's trichrome stained sections from the GSE (Figs.4c-d), Cap (Figs.4e-f) and the combined GSE\&Cap (Figs.4g-h) were closely similar to that of the control group.

$5 \mathrm{FU}$ treated rats revealed increasing the density and distribution of collagen fibers intraglomerular around the congested blood vessels and peritubular within the interstitial spaces in between the renal tubules (Figs.5a-b).

On the contrary, there was a nearly normal dispersion of fine collagen fibers intraglomerular and at the boundary of renal tubules in each of GSE/5FU (Figs.5c-d), Cap/5FU (Figs.5e-f) and the combined grape seeds extract and captopril with 5-FU pretreated rats (Figs.5g-h) that appeared more or less similar to that of the control. 


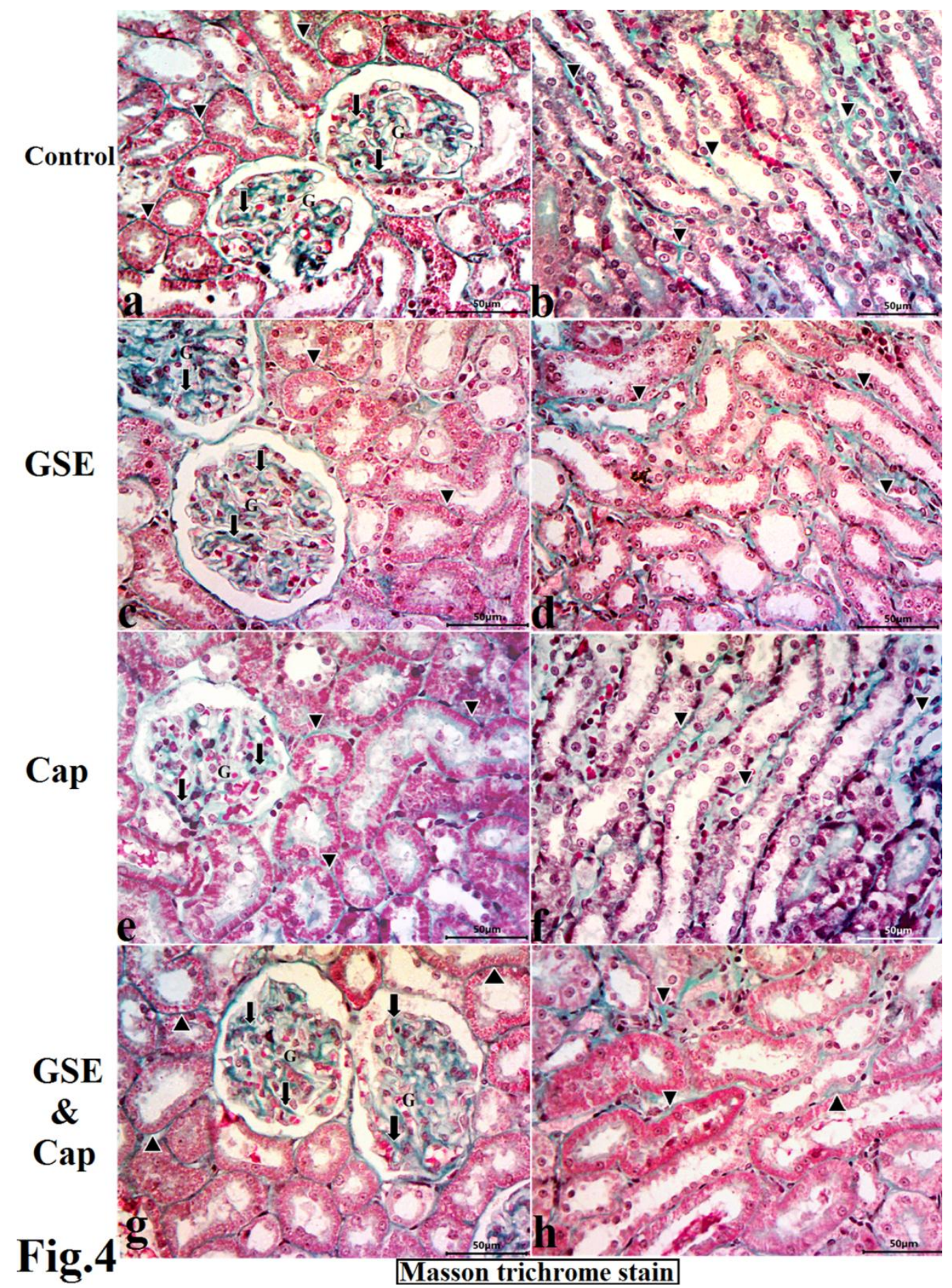

Figure (4): Control (a-b) showing: fine intraglomerular (G) collagen fibers between the glomerular tuft of capillaries (black arrow) and a scattered fine collagen fibres in the interstitium in-between the renal tubules (black arrowhead). GSE (c-d), Cap (e-f) and the combined GSE\& Cap (g-h) groups showing: nearly normal distribution of collagen fibers as the control (Masson's trichrome $X \mathbf{4 0 0}$, Scale bar; $50 \mu \mathrm{m})$. 


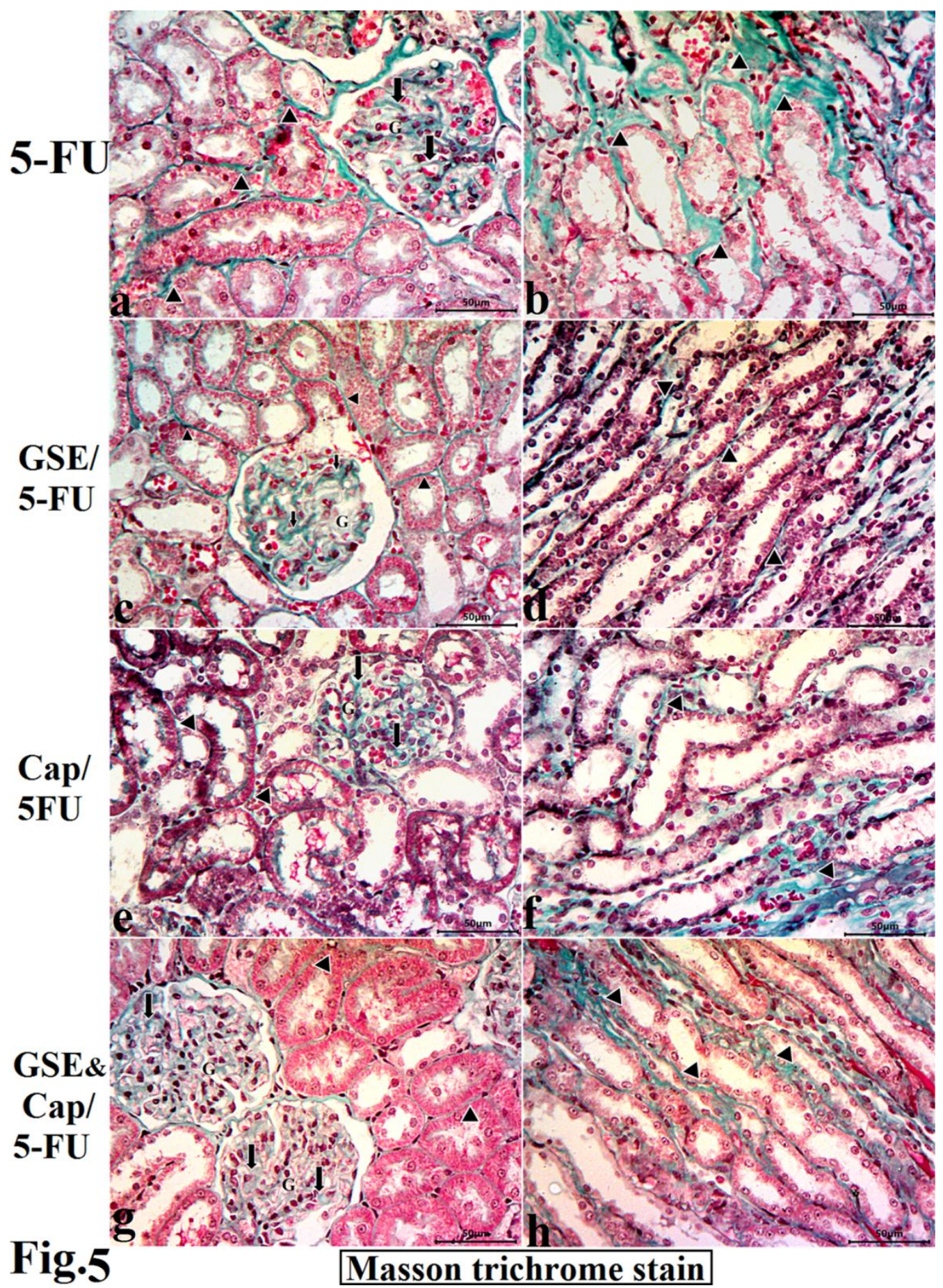

Figure (5): 5-FU treated rat (a-b) showing: increased deposition of collagen fibers intraglomerular (black arrows), pericapsular and peritubular (arrowhead) in the interstitium around the renal corpuscles. GSE/5FU (c-d), Cap/5FU (e-f) and the combined GSE\&Cap/5FU (g-h) groups showing: normal distribution of collagen fibers among the glomerular capillaries (black arrow), around the renal corpuscles and tubules (black arrowhead) nearly more or less as the control (Masson's trichrome X 400, Scale bar; 50 $\mu \mathrm{m}$ ). 
Periodic acid Schiff (PAS) reaction:

PAS stained sections of the control renal cortex revealed obvious intraglomerular strong PAS-positive reaction that was evident at the wellcircumscribed thin, regular glomerular basement membranes and tubular membranes invested the renal tubules in addition to strong reaction at the luminal brush border of the PCT. Faint PASpositive reaction at the apical tubular cells of DCT was also noticed (Fig. 6a). GSE (Fig.6b), Cap (Fig.6c) and the combined GSE\&Cap (Fig.6d) revealed the same findings as that of the control.

However, 5-FU treated group revealed faint intraglomerular PAS-positive material and even negative PAS reaction at the disintegrated brush borders of the PCTs. Focal areas of the destructed basement membrane of some tubular cells were also detected (Fig.6e).

Either captopril or GSE with 5-FU showed intraglomerular and tubular strong PAS reactions at the glomerular and tubular basement membranes, except focal areas of tubules with weak reaction at their discontinuous brush border (Figs.6f, $5 \mathrm{~g})$.

Interestingly, high restoration of the strong PAS-positive reaction was obvious in the combined grape seeds extract and captopril with 5-FU pretreated rats that appeared closely similar to that of the control group (Fig.6h). 


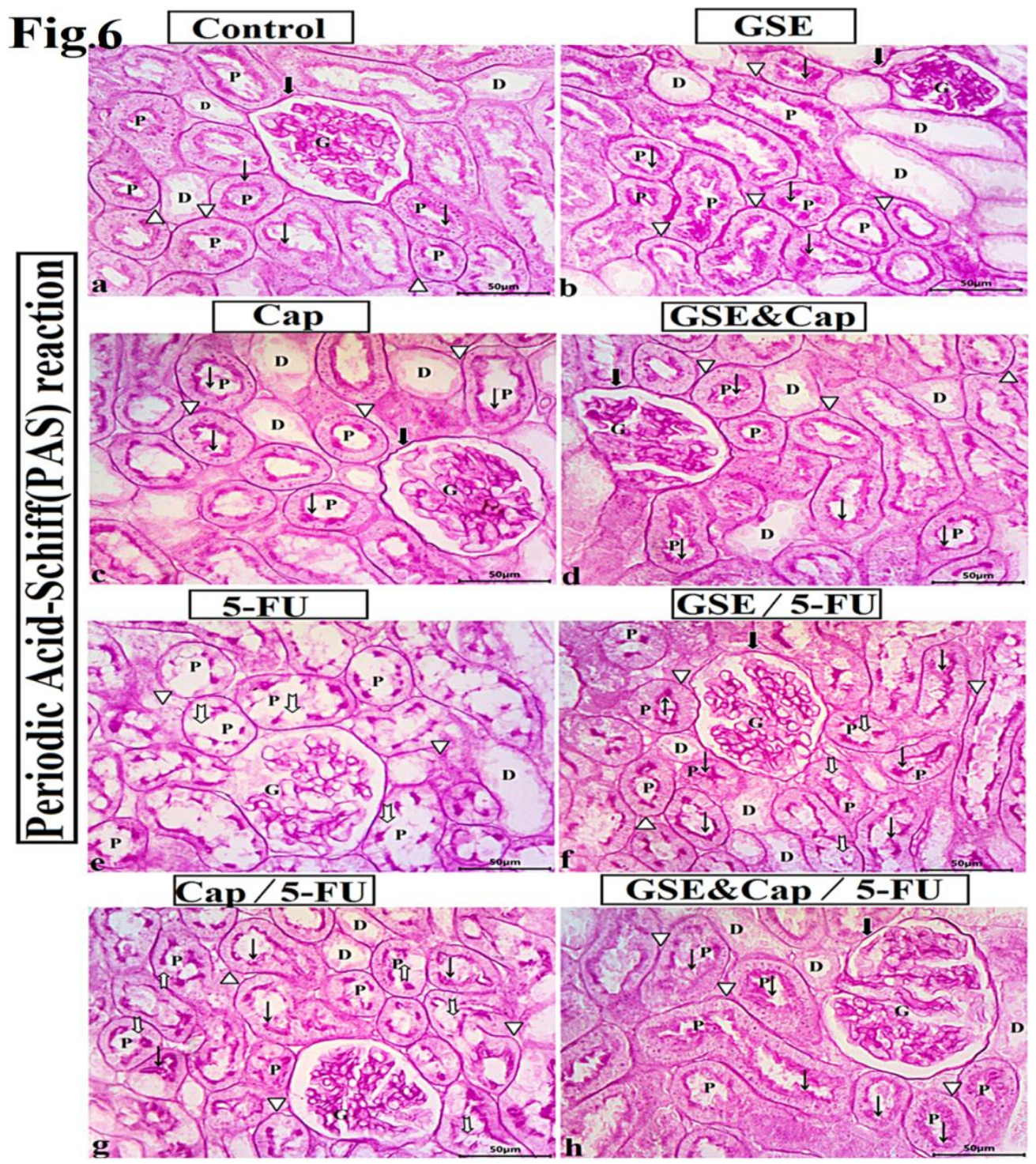

Figure (6): Control group (a) showing: strong periodic acid-Schiff (PAS) reaction in the glomeruli (G), at the capsular (thick arrow), tubular (arrowhead) basement membranes and at the intact apical brush borders (thin arrow) of the PCT (P). Notice, weak PAS-positive reaction at the apical borders of DCT (D). GSE (b), Cap (c) and the combined GSE\&Cap (d) groups showing: strong PAS-positive reaction nearly similar as that of the control. In 5-FU (e): Marked decrease in the positive reaction with no brush border (notched white arrows) in most of PCT (P), faint intraglomerular (G) PAS reaction and destructed tubular basement membrane (white arrowhead) are also noticed. GSE/5FU (f) and Cap/5-FU (g) demonstrating: strong intraglomerular (G) PAS reaction, glomerular (thick arrow), tubular membranes (arrowhead) and at the apical brush border (thin arrow) of the PCT (P) with focal interruption (notched white arrows). GSE\&Cap/5-FU (h) showing: strong intraglomerular (G) PASpositive reaction at the glomerular (thick arrow) and tubular membranes (arrowhead) and at the apical brush border (thin arrows) of PCT (P) closely similar to that in the control (periodic acid-Schiff reaction $x$ 400, Scale bar; 50 $\mu \mathrm{m})$. 


\section{Immunohistochemical results:}

The expression of iNOS immunopositivity was undetectable in all proximal \&distal convoluted tubules, and within the glomeruli of the renal cortex in the control group (Fig.7a). Interestingly, GSE (Fig.7b), Cap (Fig.7c) and the combined GSE\& Cap (Fig.6d) groups gave the similar results compared to the control group.
Conversely, iNOS immunoreactivity was markedly detected in 5FU group that showed strong dark brown cytoplasmic immunoreaction in cells of all cortical tubules and glomeruli (Fig.7e).

Inversely, GSE/5-FU (Fig.7f), Cap/5FU (Fig.7g) and GSE\&Cap/5FU pretreated rats (Fig.7h) revealed nearly undetectable iNOS immunopositive cells that appeared closely similar to that in the control group. 


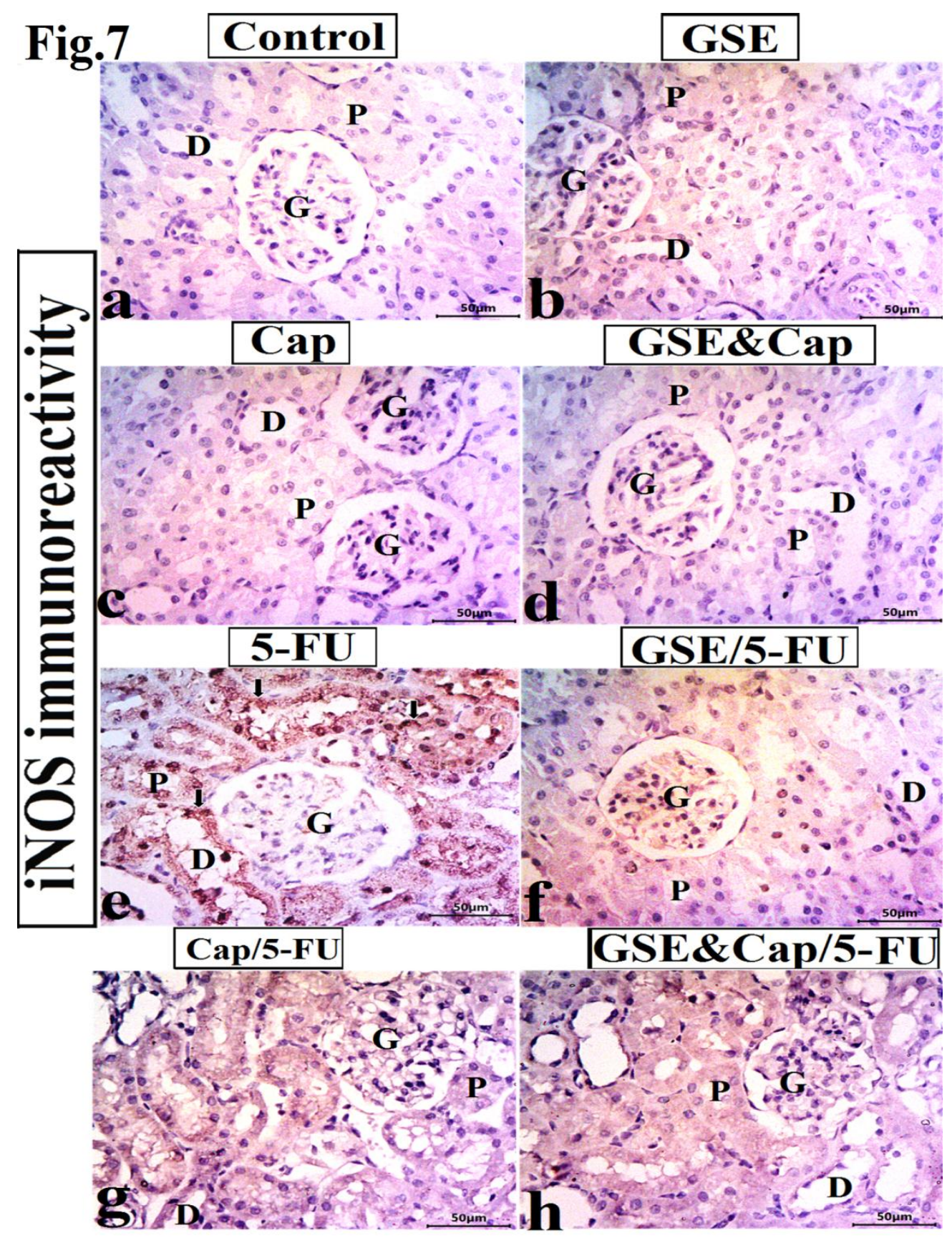

Figure (7): control (a) showing: negative iNOS immunoreaction with undetectable immunohistostaining cells in all proximal (P) \& distal (D) tubules and glomerulus (G). GSE (b), Cap (c) and the combined GSE\& Cap (d) groups showing: tubular and glomerular immunoreactions are closely similar to that in the control. 5-FU (e) showing: strong dark brown cytoplasmic immunoreaction in cells (thick arrows) of all proximal and distal (P\&D) tubules. GSE/5FU (f), Cap/5-FU (g) and GSE\&Cap/5-FU (h) showing: undetectable iNOS immunopositive cells in the glomeruli (G), all proximal (P) and distal (D) tubules closely similar to the control group (iNOS immunoreaction, $x$ 400, Scale bar; $50 \mu \mathrm{m})$. 


\section{Histo-morphometric results:}

In Table 3, 5FU treated rats recorded the highest mean values of the glomerular diameter (GD), proximal convoluted tubule (PCT-D) and distal convoluted tubule (DCT-D) diameters in H\&E stained sections $[\mathrm{P}<0.001]$ versus the control group. Similarly, the highest mean area $\%$ of collagen in Masson's trichrome stained sections, was among the 5-FU treated rats, when compared to the control rats $[\mathrm{P}<$ 0.001]. On the other hand, the least mean optical density of PAS in PAS stained sections, was observed in 5-FU treated rats when compared to the control rats $[\mathrm{P}$ $<0.001]$.

Inversely, co-administration of either GSE or captopril with 5-FU ameliorated the destructive effect of 5-FU on the renal tissue as demonstrated by significant reduction in the glomerular and tubular diameters, the mean area $\%$ of collagen and in the mean area $\%$ of the iNOS immunoreactive cells coupled with significant increase in the mean optical density of PAS . Marked improvement in the all measured parameters was among the combined GSE \& Cap/5-FU pretreated group that recorded the least mean values in glomerular and tubular diameters, in the mean area $\%$ of collagen and in the mean area $\%$ of the iNOS coupled with the highest mean value in the optical density of PAS when compared to the 5FU-treated group $[\mathrm{P}<0.001]$. This improvement in the measured parameters could nearly reach to the control values as there was no significant difference when compared to the corresponding groups (GSE,Cap and GSE\& Cap) (Table 3).

Table (3): One-way ANOVA comparative statistical analysis of the mean Glomerular diameter, diameters of proximal convoluted tubule, distal convoluted tubule, the mean optical density of PAS, the mean area \% of collagen and the mean area \% of iNOS immunoreactivity in rats of different groups

\begin{tabular}{|c|c|c|c|c|c|c|c|c|c|}
\hline $\begin{array}{l}\text { Groups } \\
\text { Parameters }\end{array}$ & $\begin{array}{c}\text { Control } \\
(n=10)\end{array}$ & $\begin{array}{c}\text { GSE } \\
(n=10)\end{array}$ & $\underset{(n=10)}{\text { Cap }}$ & $\begin{array}{c}\text { GSE\& } \\
\text { Cap } \\
(n=10)\end{array}$ & $\begin{array}{c}5 F U \\
(n=10)\end{array}$ & $\begin{array}{c}\text { GSE } \\
/ 5 F \\
(n=10)\end{array}$ & $\begin{array}{c}\text { Cap } \\
\text { /5FU } \\
(\mathbf{n}=10)\end{array}$ & $\begin{array}{c}\text { GSE\& } \\
\text { Cap } \\
\text { /5FU } \\
(\mathrm{n}=10)\end{array}$ & $P$ \\
\hline GD $(\mu \mathrm{m})$ & $\begin{array}{r}93.02 \\
\pm \quad 3.8 \\
\end{array}$ & $\begin{array}{l}92.5 \\
\pm 4.4 \\
\end{array}$ & $\begin{array}{c}98.0 \\
4 \pm 3.8 \\
\end{array}$ & $\begin{array}{l}94.2 \\
\pm 2.7 \\
\end{array}$ & $\begin{array}{c}140 \\
\pm 4.3 \mathrm{a}^{*} \\
\end{array}$ & $\begin{array}{c}92.1 \\
\pm 4.1 b^{*}\end{array}$ & $\begin{array}{c}93 \\
\pm 4.4 \mathrm{~b}^{*} \\
\end{array}$ & $\begin{array}{c}90 \\
\pm 1.7 \mathrm{~b}^{*}\end{array}$ & $<0.001$ \\
\hline $\begin{array}{c}\text { PCT-D } \\
\mu \mathrm{m})(\end{array}$ & $\begin{array}{c}37.6 \\
\pm 1.8 \\
\end{array}$ & \begin{tabular}{|l|}
37.8 \\
\pm 2.4 \\
\end{tabular} & \begin{tabular}{|l|}
41.6 \\
\pm 1.5 \\
\end{tabular} & $\begin{array}{c}39 \\
\pm 2.5 \\
\end{array}$ & $\begin{array}{c}58 \\
\pm 2.4 \mathrm{a}^{*} \\
\end{array}$ & $\begin{array}{c}41.5 \\
\pm 2.4 \mathrm{~b}^{*} \\
\end{array}$ & $\begin{array}{c}42.9 \\
\pm 3.9 b^{*} \\
\end{array}$ & $\begin{array}{c}39.2 \\
\pm 2.6 \mathrm{~b}^{*} \\
\end{array}$ & $<0.001$ \\
\hline $\begin{array}{c}\text { DCT-D } \\
\mu \mathrm{m})(\end{array}$ & $\begin{array}{r}52.4 \\
\pm 0.9 \\
\end{array}$ & $\begin{array}{l}51.8 \\
\pm 1.3 \\
\end{array}$ & $\begin{array}{l}56.6 \\
\pm 1.1 \\
\end{array}$ & $\begin{array}{l}51.9 \\
\pm 2.6 \\
\end{array}$ & $\begin{array}{c}76.3 \\
\pm 3.9 \mathrm{a}^{*} \\
\end{array}$ & $\begin{array}{c}52.6 \\
\pm 3.9 b^{*}\end{array}$ & $\begin{array}{c}56.8 \\
\pm 1.6 b^{*}\end{array}$ & $\begin{array}{c}54.8 \\
\pm 2.7 \mathrm{~b}^{*}\end{array}$ & $<0.001$ \\
\hline $\begin{array}{c}\text { Area \% of } \\
\text { collagen }\end{array}$ & $\begin{array}{c}6.4 \\
\pm 1.2\end{array}$ & $\begin{array}{c}6.4 \\
\pm 1.1 \\
\end{array}$ & $\begin{array}{c}6.7 \\
\pm 0.7\end{array}$ & $\begin{array}{c}6.8 \\
\pm 1.0\end{array}$ & $\begin{array}{c}27.1 \\
\pm 2.3 a^{*}\end{array}$ & $\begin{array}{c}8.1 \\
\pm 0.7 b^{*}\end{array}$ & $\begin{array}{c}8.5 \\
\pm 0.7 b^{*}\end{array}$ & $\begin{array}{c}7.3 \\
\pm 1.0 b^{*}\end{array}$ & $<0.001$ \\
\hline $\begin{array}{c}\text { Optical } \\
\text { density of } \\
\text { PAS } \\
\end{array}$ & $\begin{array}{c}0.8 \\
\pm 0.1\end{array}$ & $\begin{array}{c}0.7 \\
\pm 0.04\end{array}$ & $\begin{array}{c}0.7 \\
\pm 0.04\end{array}$ & $\begin{array}{c}0.8 \\
\pm 0.02\end{array}$ & $\begin{array}{c}0.3 \\
\pm 0.01 \\
a^{*} \\
\end{array}$ & $\begin{array}{c}0.6 \\
\pm 0.1 b^{*}\end{array}$ & $\begin{array}{c}0.5 \\
\pm 0.1 b^{*}\end{array}$ & $\begin{array}{c}0.7 \\
\pm 0.04 \\
b^{*}\end{array}$ & $<0.001$ \\
\hline $\begin{array}{l}\text { Area \% of } \\
\text { iNOS } \\
\text { immuno } \\
\text { reactivity }\end{array}$ & & & & & $\begin{array}{c}22 \\
\pm 4.3 \mathrm{a}^{*}\end{array}$ & $\begin{array}{c}4.9 \\
\pm 0.3 b^{*}\end{array}$ & $\begin{array}{c}3.2 \\
\pm 0.5 \\
\text { b }^{*}\end{array}$ & $\begin{array}{c}0.4 \\
\pm 0.3 b^{*}\end{array}$ & $<0.001$ \\
\hline
\end{tabular}

n:10 non overlapping fields from renal sections; GSE: grape seeds extract; Cap: captopril; 5FU: 5Fluorouracil; GD: Glomerular diameter, PCT-D: proximal convoluted tubule diameter, DCT-D: distal convoluted tubule diameter; iNOS: anti-inducible nitric oxide synthase; PAS: periodic acid-schiff reaction; SD: standard deviation; a: in comparison to all groups referred as the control; b: in comparison to the 5FU treated group. 
GRAPE SEED EXTRACT VERSUS CAPTOPRIL IN AMELIORATING 5... 603

\section{DISCUSSION}

Kidneys are extremely susceptible to drug-induced toxicity, as they are involved in filtering and concentrating different chemicals and substances (Pazhayattil and Shirali, 2014).

5 -FU is one of the extensively used chemotherapeutic agents for different human malignancies. It has severe side effects and is considered a nephrotoxic agent (Narimatsu et al., 2019).

Angiotensin-converting enzyme inhibitors (ACEI) such as captopril are effectively used as antihypertensive agents and to protect the kidney (Gelen, 2018).

Natural products from medicinal plants can ameliorate oxidative stress. Grape seeds extract (GSE), is considered an effective antioxidant compound as it is rich in catechin, epicatechin and procyanidin. Its antioxidant activity is greater than vitamins $\mathrm{C}$ and $\mathrm{E}$ (Zhang et al., 2014).

So, this study aimed to assess the probable protective role of captopril and grape seeds extract against 5-FU-induced nephrotoxicity in adult male albino rats.

In the present work, 5-FUtreated rats showed a significant decrease in the body weight that might be due to loss of skeletal muscles and adipose tissue as suggested by Badawoud et al. (2017). Song et al. (2013) attributed the decrease in the body weight to the activation of inflammatory responses that followed by the gastrointestinal malfunction.

The disturbance in serum BUN, creatinine and uric acid levels, recorded in 5-FU treated group that implied glomerular and renal dysfunction as compared to those of the control group, were parallel to those obtained by Rashid et al. (2014) who reported that 5FU caused alterations of intraglomerular blood flow and disturbance of the glomerular filtration rate (GFR). They added that 5-FU resulted in hemodynamic imbalance between vasoconstrictive and vasodilator mediators and alterations of endothelial permeability leading to increased creatinine and urea in plasma. Gelen et al. (2018) explained this disturbance by increased generation of reactive oxygen species (ROS) that has been reported in renal toxicity induced by 5 -FU.

These biochemical parameters were well correlated with the renal histological results that confirmed nephrotoxicity induced by 5-FU. The most prominent signs of kidney deterioration in $H \& E$ stained sections were in the form of glomerular hypertrophy with congested glomerular capillaries, severe tubular degeneration, cytoplasmic vacuolation, necrosis, desquamation and sloughing of tubular epithelial cells, with pyknotic nuclei and deterioration of the brush borders of the PCTs, intraluminal cast , inflammatory cell infiltration and intertubular hemorrhage.

These observations were following those of Yousef and Aboelwafa (2017) who reported that 5-FU is catabolized primarily in the liver into dihydrouracil which is then cleaved to $\alpha$-fluoro- $\beta$ alanine, ammonia, urea, and carbon dioxide that lead to nephrotoxicity.

Because of their role in concentrating and reabsorbing glomerular filtrate, renal tubules are more vulnerable to toxicity as they have high metabolic rate and their 
environment is relatively hypoxic causing increase the risk of hypoxic injury of the tubular cells (Perazella, 2012).

The exact mechanism by which 5 -FU exerts its cytotoxic effect is not fully clear. However, Chang et al. (2012) and Adela et al. (2015) reported that 5-FU resulted in high expression of inducible nitric oxide synthase (iNOS), immune cells migration concomitant with the production of numerous proinflammatory cytokines. Moreover, 5-FU induced formation of highly reactive oxidant peroxynitrite (ONOO-), which lead to DNA damage, necrosis and renal parenchymal damage. This was consistent with the significant increase in the area percentage of positive iNOS immunoreactive cells within the glomeruli and at the renal tubules that was detected in the 5FU-treated group in comparison to control.

Shubin et al. (2016) attributed the cytoplasmic vacuolation, apoptotic changes and sloughing of tubular epithelial cells to the free radicals that facilitate the release of lysosomal enzymes and subsequent oxidation of the protein architecture of the cells causing their fragmentation.

The rapid loss of brush border and the disturbance of cytoskeletal integrity as well as the disturbance of the cell junctions with miss localization of receptors involved in cell-cell adhesion may induce epithelial sloughing, apoptosis and necrotic cell death of tubular epithelium and contribute to the progressive renal tubular damage in the 5FU-treated group (Pazhayattil and Shirali, 2014).

Perazella (2012) attributed damage and deterioration of the brush borders of the PCTs to the leakages of gammaglutamyl transferase (GGT) and alkaline phosphatase (AP) enzymes that are associated with these brush borders as a result of toxin binding to them. This was consistent with the current reduction in the PAS-positive reaction with loss of the brush border and detachment of tubular cells from the basement membrane that was observed in 5-FU treated group.

El-Achkar et al. (2013) reported that the combination of the damaged brush borders of the PCTs, the sloughed tubular cells with polymerization of TammHorsfall protein and fibronectin which present in the lumen of the tubules, as a result of increasing luminal sodium concentration forms a gel-like material and could be related to intraluminal acidophilic hyaline cast formation that was observed in this study.

In the current research, the increased density and distribution of the collagen fibers within the renal interstitium of the 5FU-treated group was attributed to increase activity of mesangial cells, matrix remodeling and locally produced transforming growth factor beta (TGF- $\beta$ ) in the kidney as a consequence of the inflammatory infiltration and release numerous cytokines by ROS involved in the pathogenesis of renal fibrosis and could induced transformation of tubular epithelial cells to myofibroblast, that is the major source of extracellular matrix secretion ending up with tubular degeneration (Kendall and FeghaliBostwick, 2014). This was consistent with the significant increase in the area percentage of collagen at renal interstitium in the 5-FU group. 


\section{GRAPE SEED EXTRACT VERSUS CAPTOPRIL IN AMELIORATING 5... 605}

In the present study, either captopril or GSE co-administration with 5-FU succeeded to improve body weight, kidney function and histological structure.These results were in accordance with those of Cheah et al. (2014) and Lian et al.(2016).

Cheah et al. (2014); Bao et al. (2015) and Lian et al.(2016) reported that GSE is a combination of biologically active bioflavonoids including oligomeric proanthocyanins, and they explained the effect of GSE in alleviating renal injury through its high antioxidative effect in vivo by restoring level and activity of superoxide dismutase (SOD), catalase (CAT) and decreasing the free radicals' level, malondialdehyde (MDA), lipid peroxidation levels and inflammatory cytokines which make it a more potent radical scavenger than other known antioxidants such as vitamin $\mathrm{C}$ and $\mathrm{E}$.

Additionally, it has been shown that GSE has endothelial nitric oxide synthase (eNOS) activating and inducible nitric oxide synthase (iNOS) inhibiting effects (Cui et al., 2012).

Regarding the captopril, Morbidelli et al. (2016) attributed its cytoprotective effects through inhibition of ACE which reduces the expression of nuclear facture kappa-B (NF-kB) and the inflammatory cells infiltration that delays the progression of chronic renal failure.

Zamani et al. (2016) and Gelen et al. (2018) added that the captopril antiapoptotic capacity might be a function of its antioxidative and anti-nitro-active stress activities of its thiol group and its ability to potentiate the free radical scavenging action and antioxidant effects.
Moreover, the interference of captopril with the binding of 5-FU to DNA may explain its cytoprotective effect against undesirable side-effects of 5-FU induced nephrotoxicity (Morbidelli et al., 2016).

Presently, co-administration of captopril and GSE with 5-FU in the current study produced better effect than each one alone and synergistically restored kidney function markers to near normal.

This result was supported by Hassan et al. (2017) and Ghlissi et al. (2018) who suggested that combination of antioxidants gives better protection for the animal cell than the single drug as these antioxidants with different chemical properties synergist each other.

\section{CONCLUSION}

Co-administration of captopril and GSE has a more protective effect against 5FU-induced nephrotoxicity than either captopril or GSE alone. This effect may be mediated through antioxidative stress, as well as anti-inflammatory potentials. So, it is recommended to use grape seeds extract and captopril during chemotherapy with 5 fluorouracil to reduce its renal toxicity.

\section{REFERENCES}

1. Abdel-Aal FS, Al-Shahed FAN and AlSaeed HF. (2016): Effects of camel's milk supplementation on adult male albino rats subjected to tramadol-induced nephrotoxicity. Al-Azhar Med. J., 45(2):345-364.

2. Abdel Aziz MT, Wassef MA, Rashed LA, Mahfouz S, Omar N and Elsebaie MM. (2011): Mesenchymal Stem cells therapy in acute renal failure: possible role of hepatocyte growth factor. Journal of Stem Cell Reseach Ther., 1(3):109-115. 
3. Adela R, Nethi SK, Bagul PK, Barui AK, Mattapally S, Kuncha M, Patra CR, Reddy PN and Banerjee SK. (2015): Hyperglycaemia enhances nitric oxide production in diabetes: A Study from South Indian patients. PLoS One, 10(4): e0125270:1- 17.

4. Badawoud MH, Elshal EB, Zaki AI and Amin HA. (2017): The possible protective effect of L-arginine against 5-fluorouracilinduced nephrotoxicity in male albino rats. Folia Morphol., 76(4):608-619.

5. Bancroft JD and Layton C. (2013): The hematoxylin and eosin, connective mesenchymal tissues with their stains In: Suvarna SK, Layton C and Bancroft JD, editors. Bancroft's Theory and practice of histological techniques. 7th edition. Pbl. Churchill Livingstone: Philadelphia. PP: 173212 and 215-238.

6. Bao L, Zhang Z, Dai X, Ding $Y$, Jiang $Y$ and Li Y. (2015): Effects of grape seed proanthocyanidin extract on renal injury in type 2 diabetic rats. Molecular medicine reports, 11(1):645-652.

7. Bayomy NA, Elbakary RH., Ibrahim MAA and AbdElaziz E (2017): Effect of lycopene and rosmarinic acid on gentamicin induced renal cortical oxidative stress, apoptosis, and autophagy in adult male albino rat. The Anatomical Record, 300:1137-1149.

8. Casanova C, Moreno ML, Miranda M, Almansa I, Falcó A, Navarro A, Fustero S, Mérida $S$ and Villar VM. (2017): Antioxidant capacity of 5-Fluorouracile and new fluorinated uracil derivates. Nereis: Revista Iberoamericana Interdisciplinar de Métodos, Modelización y Simulación, (10):99-105.

9. Chang CT, Ho TY, Lin H, Liang JA, Huang HC, Li CC, Lo HY, Wu SL, Huang YF and Hsiang CY. (2012): 5-Fluorouracil induced intestinal mucositis via nuclear factor $-\kappa \mathrm{B}$ activation by transcriptomic analysis and in vivo bioluminescence imaging. PloS one, 7(3): e31808:1-8.

10. Cheah KY, Howarth GS and Bastian SEP. (2014): Grape seed extract dose-responsively decreases disease severity in a rat model of mucositis; concomitantly enhancing chemotherapeutic effectiveness in colon cancer cells. PloS one, 9(1): p.e85184:1-11.

11. Cui X, Liu X, Feng H, Zhao S and Gao $H$. (2012): Grape seed proanthocyanidin extracts enhance endothelial nitric oxide synthase expression through 5'-AMP activated protein kinase/Surtuin 1-Krüpple like factor 2 pathway and modulates blood pressure in ouabain induced hypertensive rats. Biol Pharm Bull, 35(12):2192-2197.

12. DE Moura CFG, Soares GR, Ribeiro FAP, Silva MJD, Vilegas W, Santamarina AB, Pisani LP, Estadella D and Ribeiro DA. (2019): Evaluation of the Chemopreventive Activity of Grape Skin Extract Using Medium-term Oral Carcinogenesis Assay Induced by 4-Nitroquinoline 1-Oxide. Anticancer Research, 39(1):177-182.

13. El-Achkar TM, McCracken R, Liu Y, HeitmeierMR, Bourgeois S, Ryerse $J$ and Wu XR. (2013): Tamm-Horsfall protein translocates to the basolateral domain of thick ascending limbs, interstitium, and circulation during recovery from acute kidney injury. American Journal of Physiology-Renal Physiology, 304(8):F1066-F1075.

14. Gad AM, Abd El-Raouf OM, El-Sayeh BM , Fawzy HM and Abdallah DM. (2016): Antiapototic Effect of Captopril in Cisplatin-Induced Kidney Injury in Rats. The Egyptian Journal of Hospital Medicine, 65(1): 573- 582 .

15. Gelen V, Şengül E, Yıldırım $S$ and Atila G. (2018): The protective effects of naringin against 5-fluorouracil-induced hepatotoxicity and nephrotoxicity in rats. Iran $\mathrm{J}$ Basic Med Sci., 21(4):404-410.

16. Ghlissi Z, Hakim A, Mnif H, Zeghal $K$, Rebai T, Boudawara $T$ and Sahnoun $Z$. (2018): Combined use of Vitamins $\mathrm{E}$ and $\mathrm{C}$ improve nephrotoxicity induced by colistin in rats. Saudi Journal of Kidney Diseases and Transplantation, 29(3): 545-553.

17. Hassan SM, Khalaf MM, Sadek SA and Abo-Youssef AM. (2017): Protective effects of apigenin and myricetin against cisplatininduced nephrotoxicity in mice. Pharmaceutical Biology, 55(1): 766-774. 
18. Jhun JY, Moon SJ, Yoon BY, Byun JK, Kim EK, Yang EJ, Ju JH, Hong YS, Min JK, Park SH and Kim HY. (2013): Grape seed proanthocyanidin extract-mediated regulation of STAT3 proteins contributes to Treg differentiation and attenuates inflammation in a murine model of obesityassociated arthritis. PloS one, 8(11): p.e78843:1-11.

19. Kancirová I, Jašová $M$, Waczulíková $I$, Ravingerová T, Ziegelhöffer $A$ and Ferko M. (2016): Effect of antihypertensive agents - captopril and nifedipine - on the functional properties of rat heart mitochondria. Iranian Journal of Basic Medical Sciences, 19:615623.

20. Kendall RT and Feghali-Bostwick CA. (2014): Fibroblasts in fibrosis. Novel roles and mediators. Frontiers in Pharmacology, 5(123):1-13.

21. Kotyk T, Dey N, Ashour AS, Balas-Timar D, Chakraborty S, Ashour AS and Tavares JM. (2016): Measurement of glomerulus diameter and Bowman's space width of renal albino rats. Computer Methods Programs Biomedicine, 126:143-153.

22. Lian Y, Gao L, Guo P, Zhao Y and Lin T. (2016): Grape Seed Proanthocyanidins Extract Prevents Cisplatin-induced Cardiotoxicity in Rats. Food Science and Technology Research, 22(3): 403-408.

23. Marjaneh, R.M., Khazaei, M., Ferns, G.A., Avan, A. and Aghaee- Bakhtiari, S.H. (2019): The role of microRNAs in 5- FU resistance of colorectal cancer: Possible mechanisms. Journal of Cellular Physiology, 234(3), 2306-2316.

24. Morbidelli L, Donnini $S$ and Ziche $M$. (2016): Targeting endothelial cell metabolism for cardio-protection from the toxicity of antitumor agents. CardioOncology, 2(1):3-12.

25. Narimatsu T, Kambara $\mathbf{T}$, Abe $\mathbf{H}$, Uematsu T, Tokura Y, Suzuki I and Sakamoto K. (2019): 5 Fluorouracil based adjuvant chemotherapy improves the clinical outcomes of patients with lymphovascular invasion of upper urinary tract cancer and low expression of dihydropyrimidine dehydrogenase . Oncology Letters, 17: 44294436.

26. Pazhayattil GS and Shirali AC. (2014): Drug-induced impairment of renal function. International Journal of Nephrology and Renovascular Disease, 7: 457-468.

27. Perazella MA. (2012): Drug use and nephrotoxicity in the intensive care unit. Kidney Int., 81(12):1172-1178.

28. Rashid S, Ali N, Nafees S, Hasan SK and Sultana S. (2014): Mitigation of 5Fluorouracil induced renal toxicity by chrysin via targeting oxidative stress and apoptosis in Wistar rats. Food and Chemical Toxicology, 66:185-193.

29. Salib YS, Kandeel S, El-Mehey KA, and Zamzam A-EF. (2019): Histological Study of the Effect of Proton Pump Inhibitor (Esomeprazole) on the Renal Cortex of Adult Male Albino Rats. Egyption Journal of Histology, 42 (3):624-634.

30. Shubin AV, Demidyuk IV, Komissarov AA, Rafieva LM and Kostrov SV. (2016): Cytoplasmic vacuolization in cell death and survival. Onco Target, 7(34):5586355889.

31. Singh CK, Siddiqui IA, El- Abd S, Mukhtar $H$ and Ahmad N. (2016): Combination chemoprevention with grape antioxidants. Molecular Nutrition and Food Research, 60(6): 1406-1415.

32. Song MK, Park MY and Sung MK. (2013): 5-Fluorouracil-induced changes of intestinal integrity biomarkers in BALB/c mice. Journal of Cancer Prevention, 18(4): 322-329.

33. Woloch C, Di Paolo A, Marouani H, Bocci G, Ciccolini J, Lacarelle B, Danesi R and Iliadis A. (2012): Population pharmacokinetic analysis of 5-FU and 5FDHU in colorectal cancer patients: search for biomarkers associated with gastrointestinal toxicity. Current Topics in Medicinal Chemistry, 12(15): 1713-1719.

34. Yousef HN and Aboelwafa HR. (2017): The potential protective role of taurine against 5fluorouracil-induced nephrotoxicity in adult 
male rats. Experimental and Toxicologic Pathology, 69(5): 265-274.

35. Yurdakan G, Tekin IO, Comert M, Acikgoz S, Sipahi EY. (2012): The presence of oxidized low-density lipoprotein and inducible nitric oxide synthase expression in renal damage after intestinal ischemiareperfusion. The Kaohsiung Journal of Medical Sciences, 28: 16-22.

36. Zamani Z, Nematbakhsh M, Eshraghi-Jazi F, Talebi A, Jilanchi S, Navidi M, Shirdavani S and Ashrafi F. (2016): Effect of enalapril in cisplatin-induced nephrotoxicity in rats; gender-related difference. Advanced Biomedical Research, 5: $14-22$.
37. Zhang J, Pan X, Li N, Li X, Wang Y, Liu $X$, Yin $X$ and $Y u$ Z. (2014): Grape seed extract attenuates arsenic-induced nephrotoxicity in rats. Experimental and Therapeutic Medicine, 7(1): 260-266.

38. Zhang QY, Wang FX, Jia KK and Kong LD. (2018): Natural product interventions for chemotherapy and radiotherapy-induced side effects. Frontiers in Pharmacology, 9 (1253):1-25.

39. Zhou YS, Ihmoda IA, Phelps RG, Bellamy CO and Turner AN. (2015): Following specific podocyte injury captopril protects against progressive long term renal damage. F1000 Res., 4(172): 1-15. 
أثز مستخلص بذور العنب مقابل الكابتوبريل في تحسين

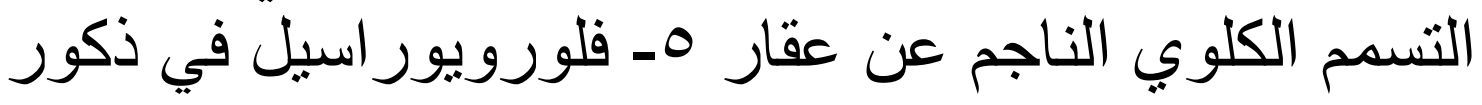

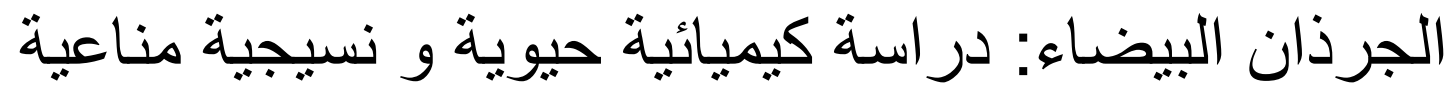

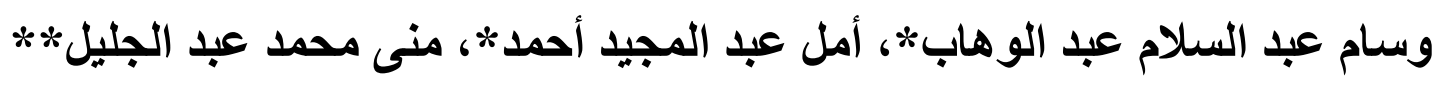
قسم الطب الثرعي والسموم الاكلينيكية، كلية الطب (بنات)، جامعة الازهر

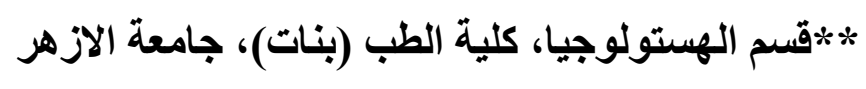

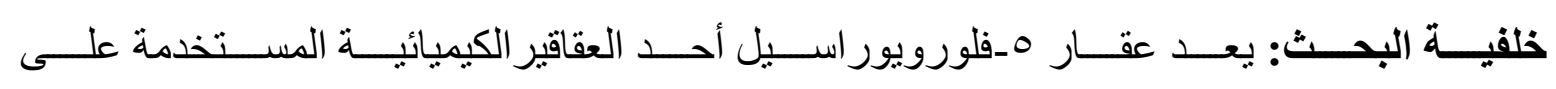

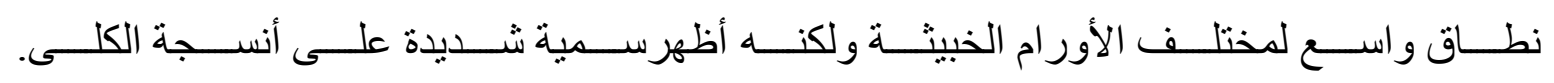

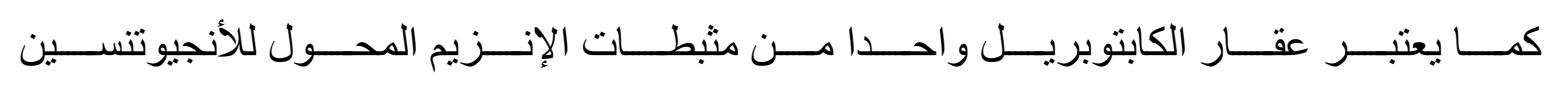

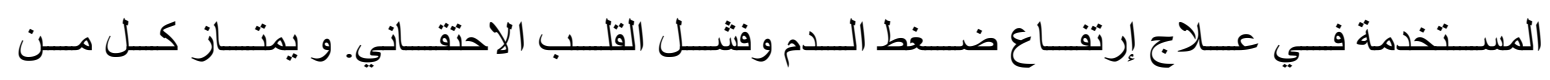

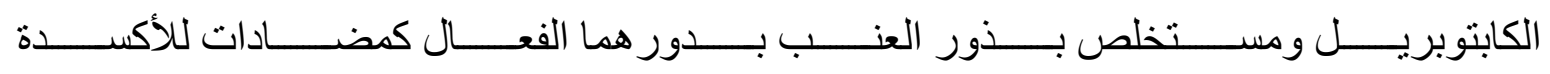
ومضادات للالتهابات لحماية هذه الأنسجة.

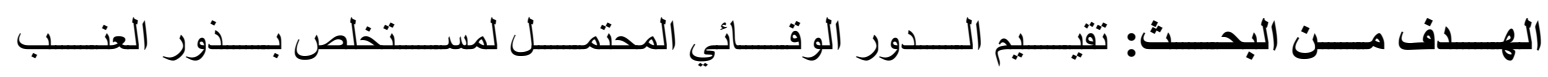

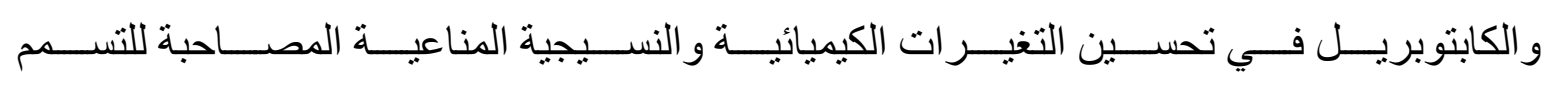
الكلوي الناجم عن عقار هـفلورويور اسيل في ذكور الجرذان البيضاء البالغة.

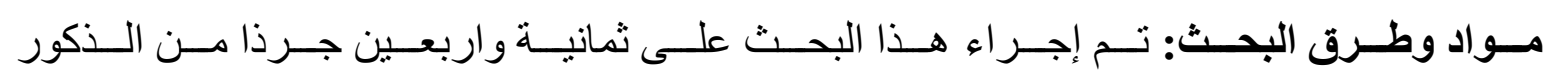
البيضاء و النى تم تقسيمهم الى ثماني مجمو عات:

المجموعة الأولى: المجموعة الضابطة.

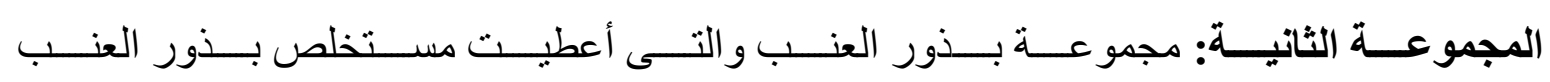
بجر عة (. .0مجم/كجم يوميا) عن طريق الفم بو اسطة أنبوب معدي.

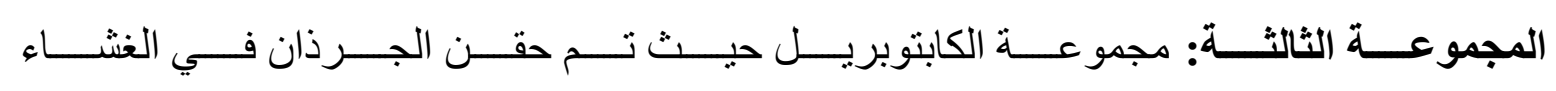
البريتوني بمحلول الكابتوبريل (• • مجم/كجم يوميا). المجموعة الرابعة: اعطيت بذور العنب و الكابتوبريل معا. 
المجموعــة الخامســـة: مجمو عـــة فلورويور اســـل ه، تـــم حقــن الجــرذان داخــل الغشــــاء

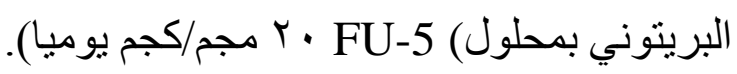

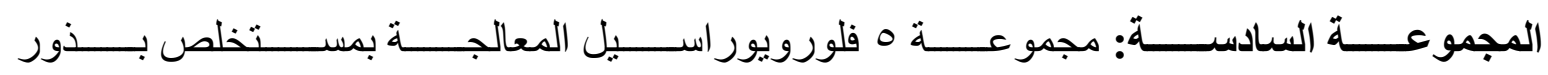
العنب.

المجموعة السابعة: مجمو عة ه فلورويور اسيل المعالجة بالكابتوبريل.

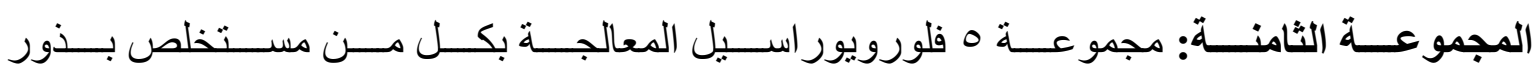
العنب و الكابتو بريل معا.

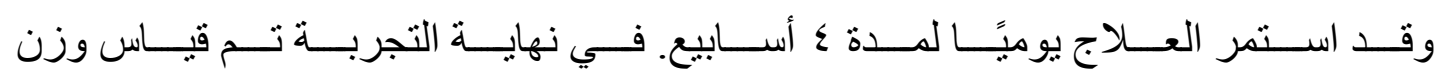

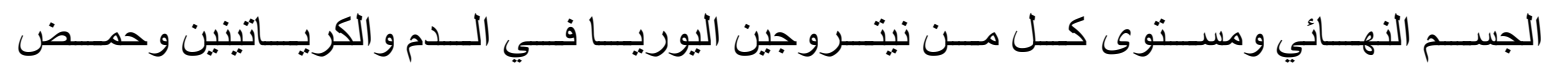

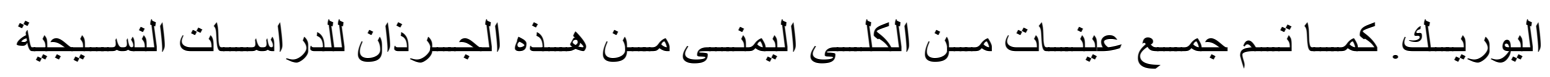
و الدر اسة الهستوكيميائية المناعية.

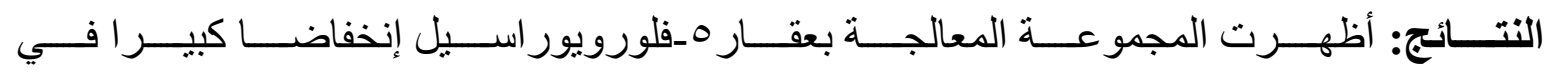

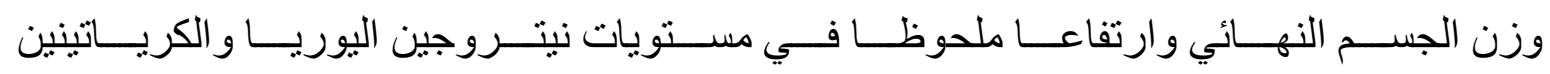

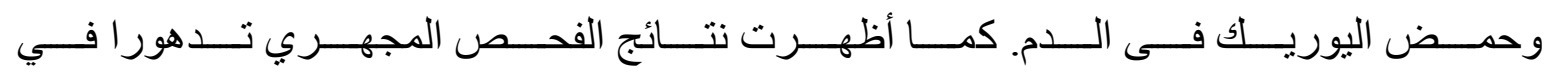

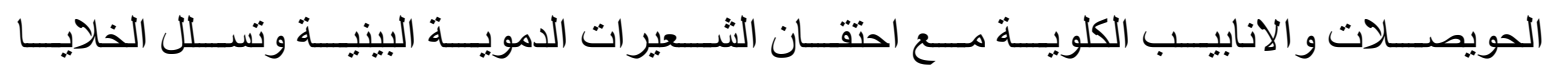

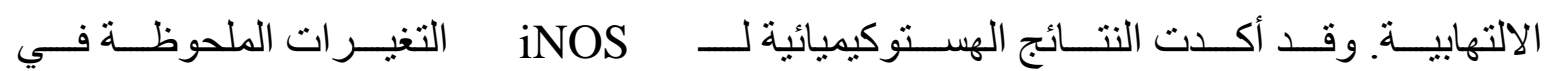

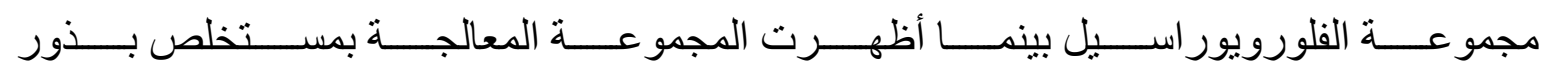

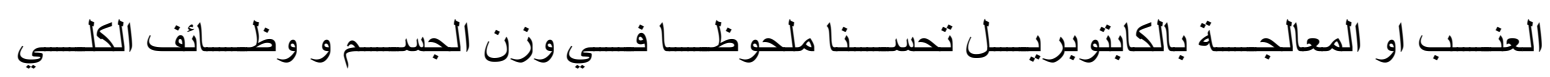

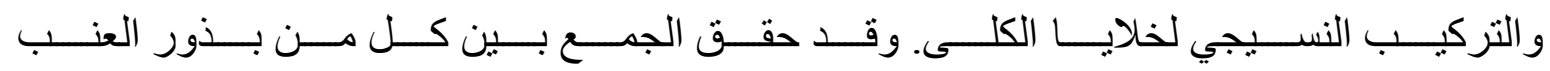
و والكابتوبريل أفضل النتائج.

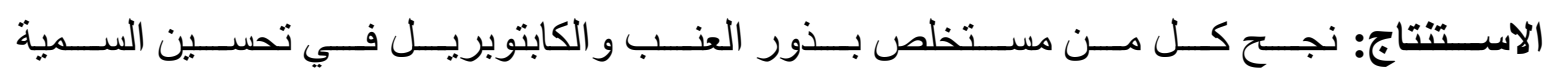
الكلوية الناجمة عن إستخدام عقار ه فلورويور اسيل خاصة عند الجمع بينهما.

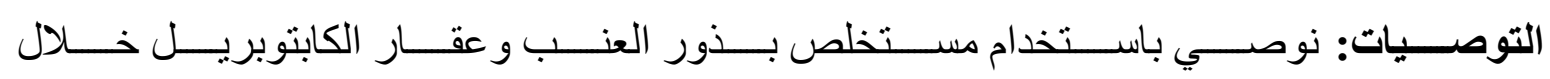
العلاج الكيميائي بعقار ه فلورويور اسيل للحد من السمية الكلوية الناجمة عند. 